\title{
The Effect of Supervision of the Principal in Increasing Teacher Performance in SMA 1 Koto Besar Dharmasraya West Sumatra
}

\author{
Wakini $^{1}$, Jamilus ${ }^{2}$ \\ ${ }^{1,2}$ Institut Agama Islam Negeri Batusangkar Sumatra Barat Indonesia \\ wakinikikin759@gmail.com
}

\begin{abstract}
Supervision carried out by principals to improve teacher performance is an important thing to continue to improve. Because it will affect the performance of teachers in carrying out their duties. Supervision can be interpreted as a service business and assistance in the form of guidance from superiors, namely the principal, to school personnel such as teachers and other officers to become proficient in accordance with the development of science. The purpose of this study was to determine the role of the principal's supervisor in improving the performance of SMA 1 Koto Besarteachers. The research method used is correlational quantitative. The subject of the study was a teacher of SMA 1 Koto Besar, which amounted to 17 people. From the results of the study it was found that the average value of the principal's supervision was 82 in the good category, and the average teacher performance score was 87.5 in the very good category. From the results of hypothesis testing, the value of Sig. of $0.016<0.05$ with a magnitude of 43.7. So it can be concluded that there is a significant relationship between principal supervision and teacher performance at SMA Negeri 1 Koto Besar.
\end{abstract}

Keywords supervision; principal; teacher performance

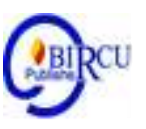

\section{Introduction}

Every educational institution has a goal to be achieved. In an effort to achieve these goals, a strategy is needed to realize quality educational services (Prestiadi \& Imron, 2020). This condition requires the principal to determine strategic steps to achieve the goals of the institution. A principal needs to adopt a transformational leadership style by maximizing all elements, being responsible for creating a conducive teaching and learning atmosphere and being able to work with teachers and education staff (Ningsih et al., 2020). One of them by giving a development program development to the elements - elements in the school both for teachers and other education personnel.

Improving the quality of human resources is needed both educators and education staff. A problem that arises in the world of education always highlights the performance of principals and teachers who are an important element in education. According to Uno (2011), teacher performance is the optimal result achieved by teachers in learning from various aspects including: quantity, quality, initiative, ability and communication. Teacher performance is defined as the ability of teachers based on the knowledge, attitudes, get e rampilan, ability and motivation to carry out a professional task of educating, teaching, guiding, directing, train, assess, evaluate students (Selamet, 2014). In line with that Amanda et al. (2016) said that teacher performance is the ability to carry out tasks at 
school and describes the existence of an activity that is displayed by the teacher in or during learning activities.

According to the results of observations made by the principal at SMA Negeri 1 Koto Besar, there are several unresolved problems, including: there are still some teachers undergoing supervision only to meet the demands of administrative obligations, namely, Teacher Performance Assessment (PKG). Teachers are not familiar with the supervision process, so they feel afraid when the principal enters the classroom to carry out observations in the context of supervision. Some teachers think that this is just an attempt to find fault. From the performance aspect, there are still many teachers who come late to school, besides that there are still many teachers who prepare RPP correctly and have not mastered the model of implementing innovative learning models well.

To solve these problems, efforts are needed to improve teacher performance by the school. One of the efforts to improve teacher performance is through the implementation of academic supervision. Assessment of teacher performance in managing learning is the process of providing an estimate of the quality of teacher performance in managing the learning process, as an integral part of a series of academic supervision. Academic supervision is a series of programs to help teachers develop their ability to manage the learning process to achieve learning objectives (Amanda et al., 2016). Teacher performance is the implementation of a plan that has been prepared through planning good learning activities that is by completing learning tools in the form of syllabus and learning implementation plans (RPP) instead planning poor learning activities if the teacher does not prepare learning tools in the form of syllabus and lesson plans. Implementation of performance is carried out by human resources who have the ability, competence, motivation, and interests (Saragih, 2019). Performance has a broader meaning, not just expressing it as a result of work, but how the work process takes place (Fauza, 2020).

Efforts to improve the quality of teachers through academic supervision is expected to have implications for the quality of student learning outcomes are better. Assessment of teacher performance in academic supervision is to see the real conditions of teacher performance to answer questions, for example, what teachers do in the classroom, what are the strengths and weaknesses of teachers in carrying out the learning process and so on. Based on the answers to these questions, information about the teacher's ability to manage learning will be obtained. Through academic supervision activities by the principal, teachers can innovate to improve the quality of learning (Zulfakar et al., 2020).

Supervision interpreted as an attempt to provide services and assistance in the form being Bingan of the head of the school for the teachers and education personnel to me have expertise in the development of science broadly follow. Academic supervision carried out by school principals is a variety of academic assistance for teachers, in the form of professional services carried out by school principals, school inspectors and supervisors and other supervisors in order to improve learning processes and outcomes (Raberi et al., 2020). Some academic principles that need to be considered are as follows: 1) being able to realize harmonious human relations, 2) being carried out continuously, 3) being carried out objectively, democratically, actively and cooperatively, 4) being integrated with educational programs in a constructive and comprehensive manner (Selamet, 2014).

From the above background, the author wants to conduct research on the effect of the implementation of supervision of the principal for improving teacher performance. The purpose of this study is to determine how the implementation of school supervision of the principal affects teacher performance. 


\section{Research Methods}

This study uses a correlational quantitative approach that is one-way. That is, this study examines the effect of principal supervision on teacher performance at SMA 1 Koto Besar. The populations in this study were all 17 teachers of SMA 1 Koto Besar. The data collection technique used a questionnaire distributed to all teachers. This study uses data collection techniques in the form of documentation of all activities related to the implementation of the supervision of the principal.

In addition, the principal also made observations, namely making direct observations of the research object to take a close look at the activities carried out. The variables in this study were the supervision of the principal as an independent variable and teacher performance as the dependent variable.

\section{Discussion}

Based on the results of descriptive analysis, it shows that the supervision of the principal at SMA 1 Koto Besar, Dharmasraya Regency is in a good category based on the average score on the assessment instrument for the supervision of the principal of 82 . While the teacher's performance is in a very good category based on an average score of 87.5 .

Based on the results of the significance test, information was obtained that the result of the $\mathrm{t}$ calculation was 3.019 and the probability (Sig.) was 0.016, which means it is smaller than the significance level of 0.05 , or Sig. $0.000<0.05$, so it can be concluded that Ho is rejected. Therefore, it can be concluded that the supervision of teacher professional principals has an effect on teacher performance.

Meanwhile, to find out how much influence the principal's supervision variable (x) has on teacher performance (y), the $\mathrm{R} 2$ value obtained is $0.437=43.7 \%$, meaning that the magnitude of the influence of variable $\mathrm{x}$ on $\mathrm{y}$ is $43.7 \%$, and the magnitude of other variables outside Principal supervision that affects teacher performance is $56.3 \%$.

Based on the results of the research above, it can be seen that there is an effect of the implementation of principal supervision of teacher performance. According to Iskandar (2013) the success of the principal is determined by the ability to understand the existence of the school as a unique and complex organization and to be able to maximize the role of the principal as a person who is given the responsibility to lead the school. The existence of a significant relationship and a positive correlation between academic supervision and teacher performance proves that the theory that states academic supervision will determine the condition of teachers and is thought to be able to improve their performance is in line with the proposed framework (Ndapaloka et al., 2016)

Supervising principals on teacher performance, a strong influence on the success of the performance of teachers (Mardalena et al., 2020). Teacher performance will greatly depend on how appropriate the supervision carried out by the principal for the development of teacher potential in managing learning. The stronger the professional competence of the teacher, the better the performance of the teacher in carrying out his duties and responsibilities, and vice versa if the teacher lacks professional competence at work, the teacher's performance will decrease.

According to Syukri et al. (2015) several things that can be pursued by school principals in implementing academic supervision to improve the performance of teachers include holding teacher meetings in schools and sending these teachers to attend upgrading, requiring all teachers to make RPP, which includes competency standards, 
competencies basis, indicators of success, and teaching materials, and collect all evaluation instruments used by teachers are then described in the final evaluation report of the lesson.

Supervise principals on teacher performance, a major influence on teacher performance success (Mardalena et al., 2020). Teacher performance will greatly depend on how appropriate the supervision carried out by the principal for the development of teacher potential in managing learning. The stronger the professional competence of the teacher, the better the performance of the teacher in carrying out his duties and responsibilities, and vice versa if the teacher lacks professional competence at work, the teacher's performance will decrease.

Supervising academic school principal function is to accommodate a variety of problems faced by teachers in the process pembelaj a rank and determine the settlement solution (Zulkiram et al., 2020). In line with that Ramadona \& Wibowo (2016) states that academic supervision functions to help encourage and provide confidence to teachers, that the teaching and learning process can and must be improved and the development of various experiences, knowledge, attitudes and skills of teachers must be assisted professionally so that teachers can develop in their work.

Its role is to seek to make small changes and to change more intensively certain teaching practices. The essence of academic supervision is not to assess teacher performance in managing the learning process, but to help teachers develop their professional abilities. Academic supervision aims to empower teachers professionally in carrying out their responsibilities so that teacher performance in the teaching and learning process can be optimal and of high quality (Ramadhan, 2017). Naturally, if the academic supervision as judging a teacher because supervision is mostly done in the form of teaching and teacher observations.

The role of teacher performance in improving quality is an important factor to produce good learning outputs and produce good human resources, which has implications for improving the quality of education (Hadi et al., 2009). The ability of teachers to teach in accordance with the demands of the standard tasks carried out has a positive effect on the results to be achieved, such as changes in student academic results, student attitudes, student skills, and changes in teacher work patterns that are increasing. Referring to the Law on Teachers and Lecturers, the competency dimensions used in this study are (1) professional, (2) pedagogic, (3) personality and (4) social (Selamet, 2014).

The following is a description of the dimensions of these competencies.

1. Professional Competence Mastering the material, structure, concept, and scientific mindset that supports the subject being taught. Mastering competency standards and basic competencies of the subjects taught. Develop creatively guided learning materials. Professional development in a sustainable manner by taking reflective actions. Utilize information and communication technology to develop themselves.

2. Pedagogic Competence Mastering the characteristics of students from the physical, moral, spiritual, social, cultural, emotional, and intellectual aspects. Mastering learning theory and educational learning principles. Develop a curriculum related to the subjects taught. Organizing educational learning. Utilize information and communication technology.

3. Personality Competence Act in accordance with Indonesian national, religious, legal, social and cultural norms. Present yourself as an honest, noble, and role model for students and the community. Present yourself as a person who is steady, stable, mature, wise, and authoritative. Demonstrate work ethic, high responsibility, pride in being a teacher, and self-confidence. Uphold the code of ethics of the teaching profession. 
4. Social Competence Be inclusive, act objectively, and do not discriminate because of considerations of gender, religion, race, physical condition, family background, and socioeconomic status. Communicate effectively and politely with fellow educators, education staff, parents, and the community. Adapt to the place of duty throughout the territory of the Republic of Indonesia which has sociocultural diversity. Communicate with the professional community itself and other professions in multimedia.

Principals are expected to have the competence to plan academic supervision programs appropriately in an effort to increase teacher professionalism (Susilo \& Sutoyo, 2019). The follow-up on the results of academic supervision must really be applied by the teacher under the supervision of the principal. So that the purpose of supervision can be achieved properly. The implementation of academic supervision must run continuously and continuously, to provide a quick response to all problems experienced by teachers. Every program implementation and learning process must find problems. However, if a quick and appropriate response is made, any problems will be easily resolved without piling up and becoming a heavy burden.

In the future, the implementation of academic supervision can begin with an assessment of teacher performance, so that it can be monitored which potentials need development and what methods are appropriate to develop this potential, then together with supervisors and teachers make plans and developments for these plans, which are in the process of preparation. Supervisors are expected to actively involve the teachers they mentor, in this case the supervisors function as facilitators, namely in the process of guiding teachers in compiling the syllabus of subjects, guiding teachers in choosing and using strategies that can develop various potential students, guiding teachers in carrying out classroom learning activities for each subject, democratic, active and sustainable (Ndapaloka et al., 2016).

\section{IV.Conclusion}

Based on the results of the research that has been carried out, it can be concluded that the implementation of the supervision of the principal at SMA 1 Koto Besar has a significant effect on improving teacher performance. Therefore, the author recommends the principal to be able to carry out continuous and continuous supervision. So that the goals of the school institution are achieved to the maximum. For further research, it is necessary to examine other variables related to teacher supervision, such as teaching motivation and teacher competence.

\section{References}

Amanda, M. O., Salam, R., \& Saggaf, S. (2016). Pengaruh Supervisi Kepala Sekolah Terhadap Kinerja Guru Di SMK Negeri 1 Bungoro Kabupaten Pangkep. SEMINAR NASIONAL "Pendidikan Ilmu-Ilmu Sosial Membentuk Karakter Bangsa Dalam Rangka Daya Saing Global,” 1(1), 149-154.

Fauza, H. (2020). The Correlation between Transformational Leadership Styles with Teacher's Performance in SMP Negeri 2 Medan. Budapest International Research and Critics in Linguistics and Education (BirLE) Journal Vol 3 (2): 1164-1169.

Hadi. Susonno.,Tukiran, Yuwono, B. (2009). . Pengaruh Supervisi Akademik, Kompetensi Guru dan Kedisiplinan Terhadap Kinerja SMA Negeri 3 Slawi Kabupaten Tegal. Jurnal Khazanah Pendidikan, 2(1), 35-64. 
https://doi.org/http://dx.doi.org/10.30595/jkp.v2i1.625

Iskandar, U. (2013). Kepemimpinan Kepala Sekolah Dalam Peningkatan Kinerja Guru. Jurnal Visi Ilmu Pendidikan, 10(1), 1018-1027. https://doi.org/10.26418/jvip.v10i1.2061

Mardalena, M., Arafat, Y., \& Fitria, H. (2020). Pengaruh Supervisi Akademik dan Kompetensi Profesional Guru terhadap Kinerja Guru di Sekolah Menengah Atas Negeri di Kecamatan Tanjung Raja. Jurnal Intelektualita: Keislaman, Sosial, Dan Sains, 9(1), 103-114. https://doi.org/https://doi.org/10.19109/intelektualita.v9i1.5582

Ndapaloka, V., Hardyanto, W., \& Prihatin, T. (2016). Pengaruh Supervisi Akademik Pengawas Dan Kepemimpinan Kepala Sekolah Melalui Motivasi Berprestasi Sebagai Mediasi Terhadap Kinerja Guru SMK Negeri Kabupaten Ende. Educational Management, 5(1), 42-54. Retrieved from https://journal.unnes.ac.id/sju/index.php/eduman/article/view/12956

Ningsih, E. K., Fitria, H., \& Fitriani, Y. (2020). Pengaruh Kepemimpinan Kepala Sekolah dan Konsep Diri Terhadap Kinerja Guru. Journal of Education Research, 1(14), 100-105. https//doi.org/https://doi.org/10.37985/joe.v1 i2.7

Prestiadi, D., \& Imron, A. (2020). Peningkatan Mutu Sumber Daya Manusia dalam Kebijakan Pendidikan Sebagai Strategi Indonesia Emas 2045. Web-Seminar Nasional (Webinar) Pendidikan "Kebijakan Pendidikan Nasional: Pendidikan NonFormal Dan Pendidikan Anak Usia Dini” Fakultas Ilmu Pendidikan - Universitas Negeri Malang, 1(1), 312-319.

Raberi, A., Fitria, H., \& Fitriani, Y. (2020). Jurnal Al - Qiyam. Qiyam, Jurnal Al, 1(2), $11-20$.

Ramadhan, A. (2017). Pengaruh Pelaksanaan Supervisi Akademik Pengawas Sekolah Dan Supervisi Kepala Sekolah Terhadap Kinerja Guru SMK Negeri Di Kabupaten Majene. Journal of Educational Science and Technology (EST), 3(2), 136. https://doi.org/10.26858/est.v3i2.3579

Ramadona, M., \& Wibowo, R. (2016). Pengaruh Supervisi Kepala Sekolah Terhadap Kinerja Guru Di SMP K 1 Penabur Pasar Baru Jakarta Pusat. Research and Development Journal of Education, 3(1), 27-34.

Saragih (2019). The Relation between the Empowerment of Teacher's Meeting and Achievement Motivation on Teacher Performances in MTsN 3 (Islamic Junior High School 3) Simalungun. Budapest International Research and Critics in Linguistics and Education (BirLE) Journal Vol 2 (2): 115-114.

Selamet, M. (2014). Pengaruh Kompetensi Supervisi Manajerial dan Supervisi Akademik Pengawas Sekolah Terhadap Kinerja Guru. Jurnal Ilmiah Mahasiswa Pascasarjana Administrasi Pendidikan, 2(1), 73-86.

Susilo, \& Sutoyo, S. (2019). Pengaruh Supervisi Akademik Kepala Sekolah terhadap Kinerja Guru. Jurnal Manajemen, Kepemimpinan, Dan Supervisi Pendidikan, 4(2), 188-193.

Syukri, Harun, C. Z., \& Usman, N. (2015). Pelaksanaan Supervisi Akademik Oleh Kepala Sekolah Untuk Meningkatkan Kinerja Guru Sekolah Dasar Pada Gugus I Uptd Dewantara Aceh Utara. Jurnal Administrasi Pendidikan Program Pascasarjana Unsyiah, 3(2), 79-90.

Uno, B. H. (2011). Teori Kinerja dan Pengukurannya. Jakarta: Bumi Aksara.

Zulfakar, Lian, B., \& Fitria, H. (2020). Implementasi Supervisi Akademik dalam Meningkatkan Kinerja Guru Zulfakar 1,. JMKSP (Jurnal Manajemen, Kepemimpinan, Dan Supervisi Pendidikan), 5(2), 230-243. 
Zulkiram, Jalaluddin, Muhammad, \& Ibrahim. (2020). Peningkatan Kinerja Profesional Guru Melalui Supervisi Akademik di SMA Negeri 1 Syamtalira Aron Aceh Utara. Serambi Konstruktivis, 2(3), 128-137.

https://doi.org/https://doi.org/10.32672/konstruktivis.v2i3.2459 